\title{
Erratum to: Nephrotoxicity of contrast media and protective effects of acetylcysteine
}

\author{
Carlo Briguori - Cristina Quintavalle • \\ Francesca De Micco • Gerolama Condorelli
}

Published online: 21 January 2011

(C) Springer-Verlag 2011

\section{Erratum to: Arch Toxicol}

\section{DOI 10.1007/s00204-010-0626-5}

Unfortunately there has been a mistake concerning the authors affiliations. It should be read correctly:

Cristina Quintavalle

Fondazione SDN, Via Gianturco 113, 80143 Naples, Italy

Gerolama Condorelli

Department of Cellular and Molecular Biology and Pathology, and IEOS, CNR, Federico II University of Naples, Via Pansini, 5, 80131 Naples, Italy

e-mail: gecondor@unina.it

The online version of the original article can be found under doi:10.1007/s00204-010-0626-5.

C. Briguori $(\bowtie)$

Clinica Mediterranea, Laboratory of Interventional Cardiology,

Via Orazio, 2, 80121 Naples, Italy

e-mail: carlobriguori@clinicamediterranea.it

C. Quintavalle

Fondazione SDN, Via Gianturco 113, 80143 Naples, Italy

F. De Micco

IRCCS Multimedica, Milan, Italy

G. Condorelli $(\varangle)$

Department of Cellular and Molecular Biology and Pathology,

and IEOS, CNR, Federico II University of Naples, Via Pansini,

5, 80131 Naples, Italy

e-mail: gecondor@unina.it 